Original Contribution

\title{
PRODUCTION PERFORMANCE AND SLAUGHTER TRAITS OF AN AUTOSEXING BROILER COMBINATION REARED EITHER SEX SEPARATE OR MIXED
}

\author{
N. Mincheva* \\ Agricultural Institute-Stara Zagora, Bulgaria
}

\begin{abstract}
Production and slaughter traits of autosexing broiler combination reared either sex separate or mixed were investigated. A total of 180 day-old feather sexed broiler chicks were divided into three groups $(\mathrm{n}=60)$ two sex separate (male and female) and one mixed (1:1), each with two replications of 30 birds. Body weight and feed intake were followed on a weekly basis; the average daily feed intake and feed conversion were calculated. By the end of the experiment (day 49), slaughter analysis was performed on 20 birds: 5 broilers from each of sex separate groups, 5 males and 5 females from the mixed group with live weight close to the group average. The carcass weight $(\mathrm{g})$, weights of carcass cuts, giblets and abdominal fat were determined. Slaughter yield and body parts ratios were calculated. The results demonstrated that sex separate rearing of broilers contributed to higher final body weight - by $6.9 \%$ in females $(\mathrm{P}<0.05)$ and by $2.9 \%$ in males $(\mathrm{P}>0.05)$, but had no effect on feed conversion. Sex separate rearing resulted in heavier carcasses by $3.6 \%(\mathrm{P}<0.05)$ and more uniform weight as compared to mixed rearing. The sex effect on body weight and slaughter traits was more considerable in males with respect to carcass, thigh, back, wings and giblets weights $(\mathrm{P}<0.05)$ but not abdominal fat whose weight was higher in female broilers $(\mathrm{P}<0.05)$.

Better uniformity of final body weight of broilers reared sex separate and the reduced variation in carcass weight and weight of cuts (breast and thigh) would facilitate slaughterhouse processing and would contribute to the realization of produce and meeting distribution network demands.
\end{abstract}

Key words: feather sexed broilers, sex separate rearing, growth, carcass traits,

\section{INTRODUCTION}

Achieving the desired slaughter weight with minimum variations is a key goal of broiler chickens production. A common problem of batches from both sexes is lack of uniformity due to the different growth potential of male and female chickens. Such flocks possess an average body weight and uniformity of two overlapping populations, whose homogeneity depends on sexual dimorphism effects (1). Therefore, for production of broilers with uniform weight, some authors (2-5) recommend sex separate rearing.

The benefits from sex separate rearing of broilers poses a dilemma to poultry farmers. Comparative data for production and slaughter

\footnotetext{
*Correspondence to: Nadya Mincheva, Agricultural Institute-Stara Zagora, Bulgaria, e-mail:minchevan@yahoo.bg
}

traits according to rearing method (mixed or sex separate) reported by researchers either give a preference to sex-separate rearing or do not report any considerable effect. Insignificant advantage of sex separate rearing of broilers during the finisher period was established by Laseinde and Oluyemi (6). Other authors confirm that mixed but not sex separate rearing of broilers was economically justified up to 8 weeks of age (7, 8). A study of Kalita et al. (9) demonstrates that sex-separate rearing was more efficient because of the higher weight gain and better feed conversion in male broilers. The authors noted the lack of problems associated with hierarchy in singlesex broiler flocks compared to mixed-sex ones. A similar observation was made also by Beg et al. (10), Yousaf (11), reporting that sexseparate fattening resulted in better performance of male broiler chickens with regard to the majority of production traits and 
in lower susceptibility to metabolic disorders. The choice of an appropriate rearing method in the view of Beg et al. (10), Samarakoon and Samarasinghe (12) and Da Costa et al. (13) would guarantee maximum profit.

Additional arguments promoting the sex separate rearing of broilers are better efficacy of slaughterhouse processing $(14,15)$. Veerapen and Driver (16) recorded substantial benefits from sex separate rearing on carcass quality and their further processing. In their opinion, male broilers attained slaughter weight earlier than females, with higher weights of breast, leg and wings cuts.

For sex separate rearing, autosexing broiler chickens are recommended as their sex is determined rapidly and accurately immediately after the hatch on the basis of external traits, wing feathers development in particular. Autosexing is based on the effect of a dominant slow-feathering gene located in the sex chromosome and its recessive allele determining the normal feathering.

In a previous study of ours, the slow-feathering gene was determined in White Plymouth Rock line L (17). As a result of selection on locus K, an experimental slow-feathering maternal form was created, which after crossing with normal feathering males would allow for sexing of hatched chicks by feathering rate. The aim of this study was to investigate production and slaughter traits in conditions of sex separate and mixed rearing in experimental feather sexing broilers.

\section{MATERIAL AND METHODS}

The 7-weeks study was performed in the experimental base of the Agricultural Institute - Stara Zagora. For the feather sexing combination of broilers, line M (Cornish) with $\mathrm{k}^{+} / \mathrm{k}^{+}$genotype (normal feathering) was used as a paternal form and an experimental White Plymouth rock line with $\mathrm{K} /$ _ (slow feathering) genotype - as a maternal form. The sex of dayold chicks was determined by observing differences in the wing feathers: female broilers were with primary feathers longer than coverts -normal feathering $\left(\mathrm{k}^{+} /{ }_{-}\right)$, whereas males - with primaries shorter than coverts or the same length -slow feathering $\left(\mathrm{K} / \mathrm{k}^{+}\right)$.

The experiment was carried out with 180 dayold sexed broiler chickens divided into three groups, each with two replicates having 30 chicks in each replicate pen with uniform weight as followed: first group: separate males, second group: separate females and third group: mixed males and females at a ratio of 1:1. Chicks were wing banded for individual identification depending on the group. The groups were reared in floor pens with wood shavings litter under optimum microclimatic parameters, uniform for all groups. Food and water were available ad libitum.

Three-stage feeding was applied: starter (1-14 days of age), grower (15-28 days of age) and finisher (29-49 days of age). Compound feeds and their nutritional content were uniform for all groups. The nutritional value of feeds was: Starter-Metabolisable energy: $12.67 \mathrm{MJ} / \mathrm{kg}$; Crude protein: $21.98 \%$; Crude fibre: $4.30 \%$; Calcium: 1.05\%; Available phosphorus: 0.46\%; Lysine: $1.38 \%$; Methionine: $0.51 \%$ and Methionine + cysteine: $0.84 \%$; GrowerMetabolisable energy: $13.12 \mathrm{MJ} / \mathrm{kg}$; Crude protein: $20.07 \%$; Crude fibre: $4.05 \%$; Calcium: 0.9\%; Available phosphorus: $0.45 \%$; Lysine: 1.23\%; Methionine: $0.45 \%$ and Methionine + cysteine: $0.76 \%$; Finisher-Metabolisable energy: $13.38 \mathrm{MJ} / \mathrm{kg}$; Crude protein: $18.03 \%$; Crude fibre: $4.02 \%$; Calcium: $0.85 \%$; Available phosphorus: $0.40 \%$; Lysine: $1.0 \%$; Methionine: $0.39 \%$ and Methionine + cysteine: $0.67 \%$.

The body weights of individual birds and feed consumption were recorded at weekly interval for each replicate. Average daily feed intake and feed conversion were calculated subsequently. Feed conversion ratio for each replicate was calculated based on the amount of feed consumed and body weight gain.

At the end of the experiment (day 49), slaughter analysis was performed on 20 birds after 12-hour fasting. Five broilers from each of sex separate groups, 5 males and 5 females from the mixed group with body weight close to the group average were selected. The carcass weight was measured after removing the blood, feathers, head, feet, and all internal organs. Carcass yield was calculated as the ratio between the carcass weight and final body weight after fasting. The breast (including bone and skin), legs (thigh and drumstick), wings, back, giblets (heart, liver and gizzard) and abdominal fat were removed from the carcass and then weighted. These data were used to calculate relative shares of breast, leg, wings and back cuts vs carcass weight. The shares of giblets and abdominal fat were calculated vs the live weight. 
The obtained results were analyzed using the statistical software package STATISTICA (StatSoft Inc., 2012). The methods of analysis of variance - one-way ANOVA (feed intake, feed conversion ratio) and two-way ANOVA (body weight, carcass traits), and post hoc LSD test were used. Assessment of significance of the differences established was carried out at the probability level of $95 \% \quad(\mathrm{P}<0.05)$. Uniformity was evaluated through coefficient of variation (\%), calculated as percentage ratio of standard deviation to mean value.

\section{RESULTS}

Data for body weight of broiler chickens depending on the rearing method and sex are presented in Table 1. At the beginning of the experiment uniformity of groups was good. The results showed that up to 5 weeks of age, average body weight was not influenced by the rearing method and afterwards, broilers reared sex separate exhibited superior results $(\mathrm{P}<0.05)$. In a study on the effect of rearing, Öztürk et al. (14) found out higher average live weight in flocks of sexed single-sex broiler chickens compared to mixed flocks by the end of the $6^{\text {th }}$ week, as well as statistically significant differences between sexes. Effects from sex separate or mixed rearing on body weight dependent on the genotype and differences became noticeable at a different age (18). At the end of the experiment, average body weight of both sexes in separately reared groups was by $103.46 \mathrm{~g}(4.7 \%)$ higher than that of the mixed group $(\mathrm{P}<0.05)$. The difference of $67.60 \mathrm{~g}$ $(2.9 \%)$ in final body weight of males in both rearing variants was insignificant $(\mathrm{P}>0.05)$, yet in favour of the sex separate group, while the comparison of females demonstrated a marked advantage of birds reared independently from the $6^{\text {th }}$ week of age onward which were by $139.40 \mathrm{~g}$ $(6.9 \%)$ heavier at the end of the experimental period than those in the mixed group $(\mathrm{P}<0.05)$. $\mathrm{Da}$ Costa et al. (18) noted that sex separate rearing had a positive effect on live weight of female broilers which was confirmed in our experiment as well while contrary to our results, males were negatively influenced, which was attributed to the competition - therefore, mixed rearing allowed attaining a higher live weight. It should be emphasized that the effect of sexual dimorphism on body weight was clearly visible for both rearing methods but at the different age. Male broilers from the mixed group grew faster and after the $4^{\text {th }}$ week were significantly heavier than females $(\mathrm{P}<0.05)$ - an advantage that was preserved until the end of the rearing period. Substantial differences between male and female broilers fattened separately appeared at 5 weeks of age $(\mathrm{P}<0.05)$. The superiority of males vs females broilers was greater in the mixed group and comprised $13-17.5 \%$ vs $10-12 \%$ in sexseparate groups. Similarly, Azahan et al. (19) reported a more pronounced difference in body weight between male and female birds reared mixed, while according to Laseinde and Oluyemi (6) sex-related differences were greater in sex separate rearing. Considerably higher body weight of male broiler chickens compared to females was reported by several authors $(9,10$, $18,20-23)$.

Table 1. Body weight of male and female broilers reared mixed or sex separate.

\begin{tabular}{|c|c|c|c|c|c|c|c|c|c|}
\hline \multirow[t]{2}{*}{ Sex } & \multirow{2}{*}{$\begin{array}{l}\text { Rearing } \\
\text { method }\end{array}$} & \multicolumn{8}{|c|}{ Body weight, g } \\
\hline & & $1 \mathrm{~d}$ & $1 \mathrm{wk}$ & $2 \mathrm{wk}$ & $3 \mathrm{wk}$ & $4 \mathrm{wk}$ & $5 \mathrm{wk}$ & $6 \mathrm{wk}$ & $7 \mathrm{wk}$ \\
\hline \multirow[t]{2}{*}{ male } & mixed & 41.21 & 130.54 & 346.92 & $626.88^{\mathrm{ab}}$ & $948.96^{\mathrm{a}}$ & $1318.50^{\mathrm{ac}}$ & $1787.70^{\mathrm{a}}$ & $2363.80^{\mathrm{a}}$ \\
\hline & separate & 41.15 & 132.76 & 346.10 & $628.67^{\mathrm{a}}$ & $947.93^{\mathrm{a}}$ & $1360.80^{\mathrm{a}}$ & $1805.60^{\mathrm{a}}$ & $2431.40^{\mathrm{a}}$ \\
\hline \multirow[t]{2}{*}{ female } & mixed & 41.13 & 122.49 & 315.07 & $563.06^{\mathrm{b}}$ & $840.00^{\mathrm{b}}$ & $1161.30^{\mathrm{b}}$ & $1521.40^{\mathrm{c}}$ & $2033.70^{c}$ \\
\hline & separate & 41.35 & 128.73 & 319.66 & $581.17^{\mathrm{ab}}$ & $863.08^{\mathrm{ab}}$ & $1232.70^{\mathrm{bc}}$ & $1638.00^{\mathrm{b}}$ & $2173.10^{\mathrm{b}}$ \\
\hline SEM & & 0.23 & 2.39 & 8.06 & 13.30 & 22.18 & 31.02 & 45.92 & 61.52 \\
\hline $\begin{array}{l}\text { Sex meal } \\
\text { male }\end{array}$ & & $627.78^{a}$ & $948.45^{\mathrm{a}}$ & $1339.63^{\mathrm{a}}$ & $1796.63^{\mathrm{a}}$ & $2397.61^{\mathrm{a}}$ \\
\hline female & & 40.99 & 125.61 & 317.36 & $572.10^{\mathrm{b}}$ & $851.54^{\mathrm{b}}$ & $1196.99^{\mathrm{b}}$ & $1579.71^{\mathrm{b}}$ & $2103.38^{\mathrm{b}}$ \\
\hline SEM & & 0.32 & 3.14 & 7.71 & 10.19 & 14.54 & 22.31 & 25.94 & 35.32 \\
\hline \multicolumn{10}{|c|}{ RM means } \\
\hline mixed & & 41.09 & 126.51 & 330.99 & 594.96 & 894.48 & 1239.89 & $1654.56^{\mathrm{b}}$ & $2198.77^{\mathrm{b}}$ \\
\hline separate & & 41.12 & 130.75 & 332.88 & 604.92 & 905.50 & 1296.73 & $1721.78^{\mathrm{a}}$ & $2302.23^{\mathrm{a}}$ \\
\hline SEM & & 0.33 & 3.38 & 11.40 & 18.81 & 31.37 & 43.86 & 64.94 & 87.00 \\
\hline \multicolumn{10}{|l|}{ ANOVA } \\
\hline S & & ns & ns & ns & * & * & ** & **** & $* * *$ \\
\hline RM & & ns & ns & ns & ns & ns & ns & * & * \\
\hline $\mathrm{S} \times \mathrm{RM}$ & & ns & ns & ns & ns & ns & ns & * & ns \\
\hline
\end{tabular}

a,b,c Means with different superscripts within a column are significantly different $(\mathrm{P}<0.05)$

$* \mathrm{P}<0.05 ; * * \mathrm{P}<0.01 ; * * * \mathrm{P}<0.001 ;$ ns-not significant; RM-rearing method, S-sex. 
Figure 1 demonstrates coefficients of variation of broilers body weight in mixed and sex separate groups. In the beginning, uniformity of broilers in each of groups was good as proved by similar coefficients of variation: $6.08,6.33$ and $6.14 \%$, for male, female and mixed groups, respectively. At the end of the experiment, the best uniformity was established in female broilers reared separately $(8.68 \%)$ followed by sex separate males (12.06\%). The mixed group was outlined with
MINCHEVA N.

the highest coefficient of variation $-14.61 \%$ e.g. least uniformity. These results were logical and resulted from the different growth potential of both sexes. According to Rondelli et al. (24) the main reason for poor uniformity of mixed broiler flocks was sexual dimorphism The data in available literature about the effects of sex separate and mixed rearing of broilers on body weights were comparable to those found by us $(4,5,18)$.

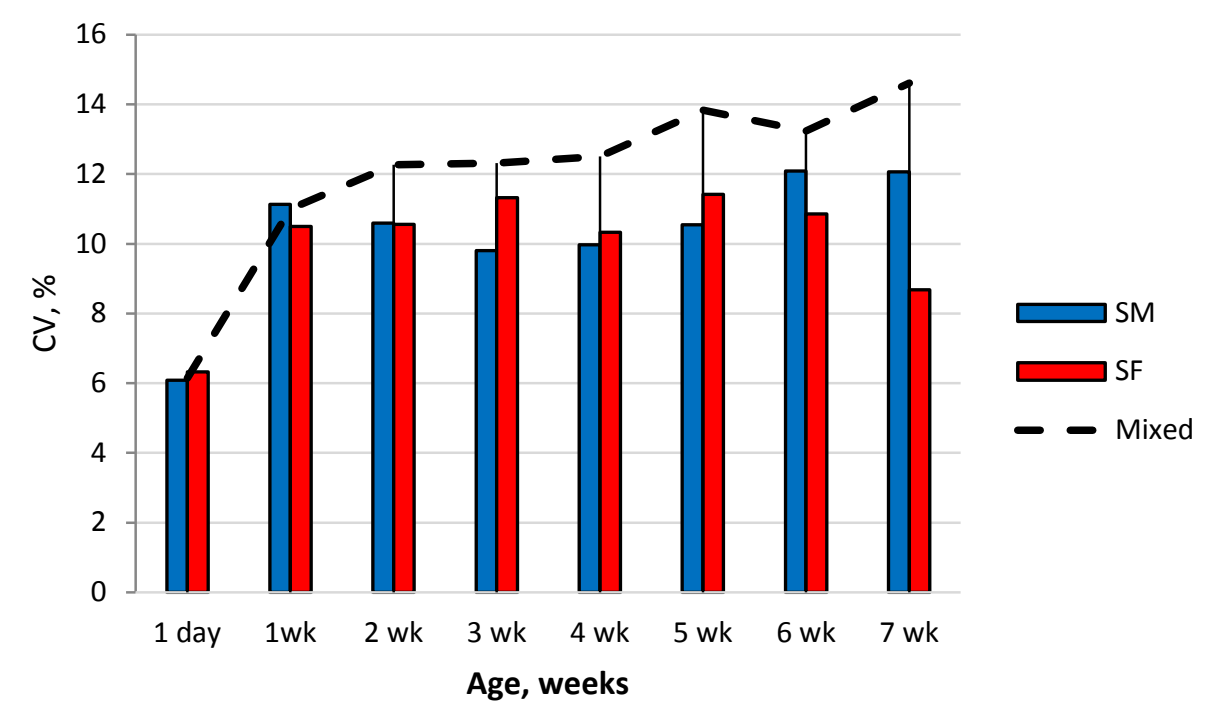

Figure 1. Body weight coefficient of variation of broilers reared mixed or sex separate SM- separate males; SF- separate female.

The results about daily feed intake of chickens at different age (Table 2) showed no considerable effect of the studied factor during the first 5 weeks of age, but then differences became statistically significant with higher values for males reared sex separate $(\mathrm{P}<0.05)$. Thus, over the entire experimental period, daily feed intake was $104.9 \mathrm{~g}$, which was by $8 \%$ and $9 \%$ more compared to the mixed group and female group respectively $(\mathrm{P}<0.05)$. Despite the presence of male broilers in the mixed group, feed intake was not higher compared to that of separately reared females, whereas Kalita et al. (9) reported higher feed intake in the mixed group compared to female group. The results for highest feed intake in separately reared male chickens confirmed the findings of other researchers $(8,14,18,19$, $25)$. On the other hand Laseinde and Oluyemi (6), Kryeziu et al. (26) did not observe any significant difference in feed intake between sexes.

Table 2. Feed intake of broilers reared mixed or sex separate.

\begin{tabular}{lccccccc}
\hline \hline Rearing method & \multicolumn{7}{c}{ Feed intake (g/day) } \\
\cline { 2 - 8 } & $0-1 \mathrm{wk}$ & $0-2 \mathrm{wk}$ & $0-3 \mathrm{wk}$ & $0-4 \mathrm{wk}$ & $0-5 \mathrm{wk}$ & $0-6 \mathrm{wk}$ & $0-7 \mathrm{wk}$ \\
\hline Mixed & 14.08 & 29.40 & 44.34 & 55.50 & 70.11 & $81.93^{\mathrm{b}}$ & $97.16^{\mathrm{b}}$ \\
SM & 15.07 & 30.61 & 47.26 & 58.49 & 74.37 & $89.13^{\mathrm{a}}$ & $104.91^{\mathrm{a}}$ \\
SF & 15.00 & 28.89 & 43.95 & 53.66 & 68.22 & $81.50^{\mathrm{b}}$ & $95.86^{\mathrm{b}}$ \\
SEM & 0.27 & 0.73 & 0.88 & 1.22 & 1.25 & 1.64 & 1.90 \\
Significance & $\mathrm{ns}$ & $\mathrm{ns}$ & $\mathrm{ns}$ & $\mathrm{ns}$ & $\mathrm{ns}$ & $*$ & $*$ \\
\hline
\end{tabular}

\footnotetext{
${ }^{\mathrm{a}, \mathrm{b}}$ Means with different superscripts within a column are significantly different $(\mathrm{P}<0.05)$
}

$* \mathrm{P}<0.05$; SM-separate males; SF-separate female.

Weekly feed conversion ratio (Table 3) did not exhibit significant between-group differences although at 5 weeks of age, feed conversion was better in male broiler chickens reared sex separate compared to the mixed group in which feed expenditure per unit weight gain was by $3.8 \%$ higher $(\mathrm{P}<0.05)$. At the end of the fattening period, differences vs female group 
MINCHEVA N.

and mixed group amounted to about $2.5-2.6 \%$ and did not show a marked effect of the tested factor $(\mathrm{P}>0.05)$. The results were comparable to those of other authors $(6,8,14,15)$ all of which affirming lack of substantial effect of sex separate or mixed rearing on feed conversion. The research of Madelindi et al. (23) also found out a similar feed conversion for both sexes despite the higher feed intake in male chickens, presuming that feed conversion in both sexes was similar. This disagreed with previous studies suggesting more efficient feed conversion in male birds compared to females as a result from better physiological potential of males to convert feed into body mass (10, $12,18,19)$.

Table 3. Feed conversion ratio of broilers reared mixed or sex separate.

\begin{tabular}{lccccccc}
\hline \hline Rearing & \multicolumn{7}{c}{ Feed conversion ratio $(\mathbf{g} / \mathbf{g})$} \\
\cline { 2 - 8 } method & $0-1 \mathrm{wk}$ & $0-2 \mathrm{wk}$ & $0-3 \mathrm{wk}$ & $0-4 \mathrm{wk}$ & $0-5 \mathrm{wk}$ & $0-6 \mathrm{wk}$ & $0-7 \mathrm{wk}$ \\
\hline Mixed & 1.158 & 1.420 & 1.628 & 1.821 & $2.047^{\mathrm{a}}$ & 2.107 & 2.207 \\
SM & 1.153 & 1.407 & 1.689 & 1.806 & $1.973^{\mathrm{b}}$ & 2.122 & 2.151 \\
SF & 1.199 & 1.450 & 1.709 & 1.828 & $2.004^{\mathrm{ab}}$ & 2.143 & 2.204 \\
SEM & 0.023 & 0.010 & 0.030 & 0.008 & 0.015 & 0.012 & 0.020 \\
Significance & $\mathrm{ns}$ & $\mathrm{ns}$ & $\mathrm{ns}$ & $\mathrm{ns}$ & $\mathrm{ns}$ & $\mathrm{ns}$ & $\mathrm{ns}$ \\
\hline
\end{tabular}

${ }^{-a, b}$ Means with different superscripts within a column are significantly different $(\mathrm{P}<0.05)$; SM-separate males; SF-separate female.

The slaughter analysis results for male and female broiler chickens reared either sex separate or mixed are presented in Tables 4 and 5. Both the rearing method $(\mathrm{P}<0.05)$, and sex $(\mathrm{P}<0.001)$ had a statistically significant effect on carcass weight but not on slaughter yield $(\mathrm{P}>0.05)$. The average carcass weight of broilers reared sex separate was by $3.6 \%$ higher than that in the mixed group $(\mathrm{P}<0.05)$, and slaughter yield comprised 65.45-66.89\% of slaughter body weight. The lack of significant sex-related differences in slaughter yield confirmed the results of Azahan et al. (19), Api et al. (22), Shim et al. (27), but not those of Lopez et al. (20), Yousaf (11) and Madelindi et al. (23), who reported substantial sex-related effects.

Table 4. Carcass weight and carcass cuts weight of male and female broilers reared mixed or sex separate.

\begin{tabular}{|c|c|c|c|c|c|c|c|c|}
\hline Sex & $\begin{array}{l}\text { Rearing } \\
\text { method }\end{array}$ & $\mathrm{CW}, \mathrm{g}$ & Breast, $\mathbf{g}$ & Leg, g & Wings, $\mathrm{g}$ & Back, $g$ & $\mathbf{G}, \mathbf{g}$ & $\mathbf{A F}, \mathbf{g}$ \\
\hline \multirow[t]{2}{*}{ male } & mixed & $1496.00^{\mathrm{a}}$ & 445.80 & $507.00^{\mathrm{a}}$ & $196.60^{\mathrm{a}}$ & $345.20^{b}$ & $87.20^{\mathrm{ab}}$ & $34.00^{b}$ \\
\hline & separate & $1546.80^{\mathrm{a}}$ & 447.40 & $520.60^{\mathrm{a}}$ & $200.40^{\mathrm{a}}$ & $374.80^{\mathrm{a}}$ & $90.40^{\mathrm{a}}$ & $33.00^{\mathrm{b}}$ \\
\hline \multirow[t]{2}{*}{ female } & mixed & $1327.60^{\mathrm{b}}$ & 416.20 & $426.60^{\mathrm{b}}$ & $177.60^{\mathrm{b}}$ & $305.80^{\mathrm{c}}$ & $82.60^{\mathrm{ab}}$ & $48.80^{\mathrm{ab}}$ \\
\hline & separate & $1378.20^{\mathrm{b}}$ & 436.40 & $428.00^{\mathrm{b}}$ & $177.00^{\mathrm{b}}$ & $331.60^{\mathrm{b}}$ & $79.40^{\mathrm{b}}$ & $53.40^{\mathrm{a}}$ \\
\hline SEM & & 22.14 & 6.47 & 11.21 & 3.31 & 6.03 & 1.84 & 3.68 \\
\hline \multicolumn{9}{|l|}{ Sex means } \\
\hline male & & $1521.40^{\mathrm{a}}$ & 446.60 & $513.80^{\mathrm{a}}$ & $198.50^{\mathrm{a}}$ & $360.00^{\mathrm{a}}$ & $88.80^{\mathrm{a}}$ & $33.50^{\mathrm{b}}$ \\
\hline female & & $1352.90^{b}$ & 426.30 & $427.30^{\mathrm{b}}$ & $177.30^{\mathrm{b}}$ & $318.70^{\mathrm{b}}$ & $81.00^{\mathrm{b}}$ & $51.10^{\mathrm{a}}$ \\
\hline SEM & & 16.23 & 8.69 & 6.72 & 3.09 & 6.83 & 2.26 & 4.29 \\
\hline \multicolumn{9}{|l|}{ RM means } \\
\hline mixed & & $1411.80^{b}$ & 431.00 & 466.80 & 187.10 & $325.50^{\mathrm{b}}$ & 84.90 & 41.40 \\
\hline separate & & $1462.50^{\mathrm{a}}$ & 441.90 & 473.30 & 188.70 & $353.20^{\mathrm{a}}$ & 84.90 & 43.20 \\
\hline SEM & & 31.32 & 9.14 & 15.86 & 4.69 & 8.53 & 2.61 & 5.19 \\
\hline \multicolumn{9}{|l|}{ ANOVA } \\
\hline $\mathrm{S}$ & & $* * *$ & ns & $* * *$ & $* * *$ & $* * *$ & $*$ & $*$ \\
\hline $\mathrm{RM}$ & & $*$ & ns & $\mathrm{ns}$ & $\mathrm{ns}$ & $* *$ & ns & ns \\
\hline$S \times R M$ & & ns & ns & ns & $\mathrm{ns}$ & ns & ns & ns \\
\hline
\end{tabular}

\footnotetext{
${ }^{\mathrm{a}, \mathrm{b}, \mathrm{c}}$ Means with different superscripts within a column are significantly different $(\mathrm{P}<0.05)$ $* \mathrm{P}<0.05 ; * * \mathrm{P}<0.01 ; * * * \mathrm{P}<0.001 ;$ ns- not significant,

RM- rearing method; S- sex; CY- carcass yield; G-giblets; AF- abdominal fat
} 
MINCHEVA N.

Table 5. Percentages of carcass cuts, giblets and abdominal fat of male and female broilers reared mixed or sex separate.

\begin{tabular}{|c|c|c|c|c|c|c|c|c|}
\hline Sex & $\begin{array}{l}\text { Rearing } \\
\text { method }\end{array}$ & CY, \% & Breast, \% & Legs, \% & Wings, \% & Back, \% & $\mathrm{G}, \%$ & $\mathrm{AF}, \%$ \\
\hline \multirow[t]{2}{*}{ male } & mixed & 65.45 & $29.79^{\mathrm{bc}}$ & $33.91^{\mathrm{a}}$ & 13.14 & 23.07 & 5.83 & $1.50^{\mathrm{b}}$ \\
\hline & separate & 65.77 & $28.91^{\mathrm{b}}$ & $33.66^{\mathrm{ac}}$ & 12.97 & 24.23 & 5.84 & $1.41^{\mathrm{b}}$ \\
\hline \multirow[t]{2}{*}{ female } & mixed & 66.89 & $31.32^{\mathrm{ac}}$ & $32.13^{b c}$ & 13.37 & 23.07 & 6.23 & $2.46^{\mathrm{a}}$ \\
\hline & separate & 66.78 & $31.67^{\mathrm{a}}$ & $31.05^{\mathrm{b}}$ & 12.84 & 24.07 & 5.76 & $2.59^{\mathrm{a}}$ \\
\hline SEM & & 0.35 & 0.39 & 0.37 & 0.14 & 0.23 & 0.11 & 0.19 \\
\hline \multicolumn{9}{|l|}{ Sex means } \\
\hline male & & 65.61 & $29.35^{\mathrm{b}}$ & $33.78^{\mathrm{a}}$ & 13.06 & 23.65 & 5.84 & $1.46^{\mathrm{b}}$ \\
\hline female & & 66.84 & $31.49^{\mathrm{a}}$ & $31.59^{\mathrm{b}}$ & 13.11 & 23.57 & 6.00 & $2.53^{\mathrm{a}}$ \\
\hline SEM & & 0.45 & 0.42 & 0.39 & 0.20 & 0.37 & 0.16 & 0.20 \\
\hline \multicolumn{9}{|l|}{ RM means } \\
\hline mixed & & 66.17 & 30.56 & 33.02 & 13.26 & $23.07^{\mathrm{b}}$ & 6.03 & 1.98 \\
\hline separate & & 66.28 & 30.29 & 32.35 & 12.91 & $24.15^{\mathrm{a}}$ & 5.80 & 2.00 \\
\hline SEM & & 0.49 & 0.55 & 0.52 & 0.20 & 0.33 & 0.16 & 0.27 \\
\hline \multicolumn{9}{|l|}{ ANOVA } \\
\hline $\mathrm{S}$ & & ns & $* *$ & $* * *$ & ns & $\mathrm{ns}$ & ns & $* *$ \\
\hline RM & & ns & ns & ns & ns & $*$ & ns & ns \\
\hline $\mathrm{S} \times \mathrm{RM}$ & & ns & ns & ns & ns & $\mathrm{ns}$ & ns & ns \\
\hline
\end{tabular}

Data about the most valuable carcass cuts (breast and leg) exhibited significant differences with regard to sex but not to rearing method. As expected, the proportion of breast from carcass weight in male broilers was lower than that in females but only for sex separate groups: $28.91 \%$ vs $31.67 \%(\mathrm{P}<0.05)$, while absolute weight ranged between 416 and $447 \mathrm{~g}$. On the other hand, the absolute and relative weights of thigh and drumstick was superior in male broilers with differences of $80.4 \mathrm{~g}$ and $1.78 \%$ (in mixed rearing) and by $92.6 \mathrm{~g}$ and $2.61 \%$ (in sex separate rearing), $\mathrm{P}<0.05$. Some studies also confirmed higher proportion of breast in female broiler chickens, but the share of thigh and drumstick was lower $(24,28)$. In agreement with our data, Da Costa et al. (18) did not found out any significant differences in breast and leg weight between male or female birds from both rearing variants. Analyzing the rearing method effect, the researchers reported higher values for males reared sex separate compared to both mixed group and female group. A considerable effect of rearing method on weights of breast, leg and back was reported also by Sam et al. (8)

For less valuable carcass cuts (wings and back), sex was also relevant, with superiority of males: $196.6 \mathrm{~g}$ in males vs $177.60 \mathrm{~g}$ in females in mixed rearing and $200.4 \mathrm{~g}$ in males vs $177 \mathrm{~g}$ in females in sex separate rearing for wing weight $(\mathrm{P}<0.05)$. Respective relative weights from carcass weight ranged within $12.84-13.37 \% \quad(P>0.05)$. The weight of the back, being an indirect parameter of skeletal development, was by $13 \%$ higher in males compared to that of females in mixed and sex separate rearing $(\mathrm{P}<0.05)$. There was a difference of $8.5 \%$ in favour of sex separate rearing as well $(\mathrm{P}<0.05)$. In general, this explained the highest share of the back from carcass weight in separately reared broiler chickens $(\mathrm{P}<0.05)$. Laseinde and Oluyemi (6) reported differences in back and wings weights between male and female broilers with superiority of males when they were reared together but not when reared sex separate. Comparable to our results were reported by other researchers $(26,29,30)$, namely heavier back, thigh and drumstick, wings in male broilers.

The weight of giblets (heart, liver, gizzard) and abdominal fat did not differ substantially with respect to rearing method. They were rather influenced by sex, with significantly higher values of giblets but not abdominal fat in males vs females in the sex separate groups $(\mathrm{p}<0.05)$. For both methods, abdominal fat percentages was higher in female birds $(\mathrm{P}<0.05)$. Available literature reports $(19,25,23)$ acknowledged that abdominal fat deposition in females was greater and determined by specific metabolic features. Öztürk et al. (14) did not found 
differences between sex separate and mixed rearing with regard to weight of internal organs - liver, heart and gizzard, as well as abdominal fat, in line with our results.

Figure 2 depicts coefficients of variation of carcass weight and breast and leg weights in both rearing methods. It should be noted that each sex had a specific level of uniformity.
The best uniformity was achieved in female broilers reared sex separate as confirmed by the lowest coefficients of variation (from 1.7\% to $3.3 \%$ ) followed by male broilers reared sex separate $(2.04-6.08 \%)$. The variation in studied traits was the greatest in the mixed group - from $7.44 \%$ to $10.36 \%$, resulting in lower uniformity.

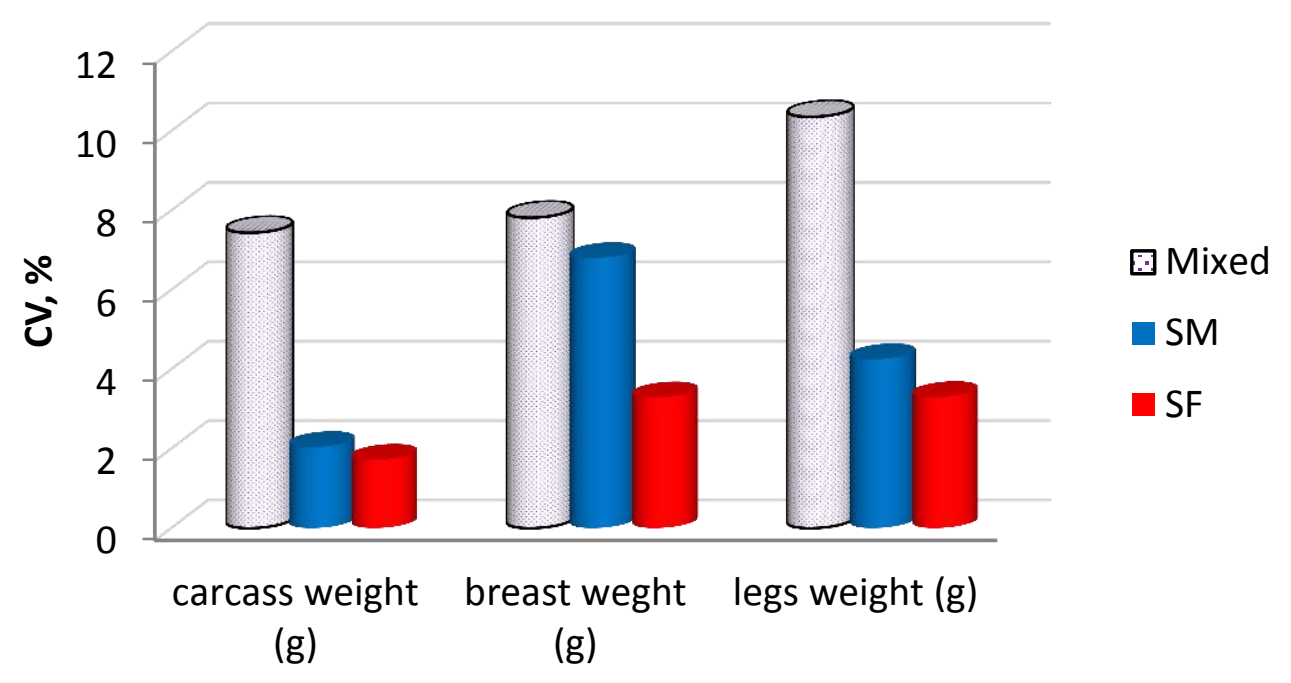

Figure 2. Coefficients of variation of carcass weight and breast and leg cuts weights of broilers reared mixed or sex separate.

\section{CONCLUSION}

Our results suggest that sex-separate broiler rearing can have a positive effect on their productive performances and will lead to better uniformity of the final body weight and carcass weight.

\section{REFERENCES}

1. Belorechkov, D., Uniformity of broiler chickens - contemporary problems in industrial poultry farming. Poultry Farming, 3: 8-10, (Bg), 2007.

2. Toudic C., Evaluating uniformity in broilers factors affecting variation, https://thepoultrysite.com/articles/evaluatinguniformity-in-broilers-factors-affectingvariation, 2007.

3. Streltsov, V. A., Hramchenkova, A.O., Martishina, N. A., Organisation of sex separate rearing of day-old broiler chickens. Agrokonsultant: 31-34, (Rus), 2014.

4. Gous, R.M., Nutritional and environmental effects on broiler uniformity. World's Poultry Science Journal, 74, (1): 21-34, 2018.

5. Kalita, S., Kalita, K., Kalita, N., Mahanta, J., Ahmed, H., Islam R., Effect of sex separate rearing on uniformity of commercial broiler chicken reared in deep litter system. International Journal of Livestock Research, 8 (1): 79-83, 2018.
6. Laseinde E.A.O. and Oluyemi, J.A., Effect of sex separation at the finisher phase on the comparative growth performance, carcass characteristics and breast muscle development between male and female broiler chickens. Nigerian Journal of Animal production, 21: 11-18, 1994.

7. Akpa, G. N., Sam, I. M., Iyeghe-Erakpotobor, G. I., Alphonsus, C., Effect of rearing methods on growth characteristics of broilers. Proceeding $35^{\text {th }}$ Conference, Nigerian Society for Animal Production, University of Ibaden, Nigeria, 14-17 March, 2010.

8. Sam, I.M., Akpa, G.N., Alphonsus. C., Iyeghe-Erakpotobor, G. I., Agubosi, O.C.P., Effect of sex separation on growth performance and carcass characteristics of broilers raised to maturity. Continental Journal of Animal and Veterinary Research, 2: 35-40, 2010.

9. Kalita, S., Kalita, K., Kalita, N., Mahanta, J., Performance of commercial broiler chicken under sex separate rearing in deep litter system. International Journal of Livestock Research, 8 (5): 129-135, 2018.

10.Beg, M.A.H., Saiful Islam, K.B.M., Aftabuzzaman, M., Mahbub, A.S.M., Effects of separate sex growing on performance and metabolic disorders of broilers. International 
Journal of Animal Resources, 1 (1): 19-26, 2016.

11. Yousaf, A., Impact of gender determination through vent sexing on Cobb-500 broiler performance and carcass yield. Journal of Animal and Feed Research, 6 (6): 125-129, 2016.

12.Samarakoon, S.M.R. and Samarasinghe., K., Strategies to improve the cost effectiveness of broiler production. Tropical Agricultural Research, 23 (4): 338-346, 2012.

13.Da Costa, M.J., Colson, G., Frost, T.J., Halley, J., Pesti, G.M., Evaluation of starter dietary digestible lysine level on broilers raised under a sex-separated or straight-run housing regime, part 2: Economics of sex separation and digestible lysine level for maximum returns. Poultry Science, 96: 32823290, 2017.

14.Öztürk, E., Sarica, M., Saylam, K., Yildirim, A., Effect of sex separated broiler growing on performance and carcass traits. Journal of Agricultural Faculty,OMU, 13 (1): 33-45, 1998.

15.de Albuquerque, R., L.K. Marchetti, A.C.A. Fagundes, L.C. Bittencourt, M.A. da Trindade Neto, de Lima, F.R., Efeito de diferentes densidades populacionais e do sexo sobre o desempenho e uniformidade em frangos de corte. Brazilian Journal of Veterinaty Research and Animal Science, 43: 581-587, 2006.

16.Veerapen, D.S. and Driver, B.M.F., Separate sex growing of Ross 208 broilers and effects on broiler performance and carcass quality. Science and Technology Research Journal, University of Mauritius, Vol. 4: 145-159, 1999.

17. Mincheva, N., Lalev, M., Oblakova, M., Hristakieva, P., Ivanova, I., Investigation on the frequency of alleles at the $\mathrm{K}$ locus and their effect on the growth of two lines of Plymouth Rock chickens. Archiva Zootechnica, 15 (1): 69-75, 2012.

18.Da Costa, M.J., Zaragoza-Santacruz, S., Frost, T.J., Halley, J., Pesti, G.M., Straightrun vs. sex separate rearing for 2 broiler genetic lines Part 1: Live production parameters, carcass yield, and feeding behavior. Poultry Science, 96: 2641-2661, 2017.

19.Azahan, E.A.E., Marini, A.M., Noraziah, M., Evaluation on the effects of sex on growth and carcass characteristics of broilers. Journal of Tropical Agriculture and Food Science, 35 (2): 313-318, 2007.

20.Lopez, K.P., Schilling, M.W., Corzo, A., Broiler genetic strain and sex effects on meat
MINCHEVA N.

characteristics. Poultry Science, 90: 11051111, 2011.

21.Kalita K.P. and Sapcota, D., Sex separate rearing of broiler chickens. Poultry Punch, 61-62, 2014.

22.Api, I., Takahashi, S., Signor, A.,Paixão, M.S.J., Refati, R., Restelatto, R., Effect of strain and sexing on performance and carcass yield of broilers. Ciência Animal Brasileira, Goiânia, v.18, 1-10, 2017.

23. Madilindi, M.A., Mokobane, A., Letwaba, P.B., Tshilate, T.S., Banga, C.B, Rambau, M.D.,

Bhebhe E., Benyi, K., Effects of sex and stocking density on the performance of broiler chickens in a subtropical environment. South African Journal of Animal Science, 48 (3): 459-468, 2018.

24.Rondelli, S., Martinez, O., García, P.T., Sex effect on productive parameters, carcass and body fat composition of two commercial broilers lines. Brazilian Journal of Poultry Science, 5 (3): 169-173, 2003.

25.Hernawan E., Wahyuni S., Suprapti, H., The levels of blood glucose, truglyceride, final body weight and abdominal fat percentage of broiler under sex separated and straight run rearing system. Lucrări Ştiinţifice - Seria Zootehnie 57: 28-33, 2012.

26.Kryeziu, A.J., Mestani, N, Berisha, Sh. and M.A. Kamberi, M.A., The European performance indicators of broiler chickens as influenced by stocking density and sex. Agronomy Research 16 (2): 483-491, 2018.

27.Shim ,M.Y., Tahir , M., Karnuah , A.B., Miller, M., Pringle, T.D., Aggrey , S.E., Pesti, G.M., Strain and sex effects on growth performance and carcass traits of contemporary commercial broiler crosses. Poultry Science, 91: 2942-2948, 2012.

28.Del Castilho, C.C., Santos, T.T., Rodrigues, C.A.F., and R.A. Torres Filho, R.A., Effects of sex and genotype on performance and yield characteristics of free range broiler chickens. Arquivo Brasileiro de Medicina Veterinaria e Zootecnia, 65 (5): 1483-1490, 2013.

29.Benyi, K., Tshilate, T.S., Netshipale, A.J., Mahlako, K.T., Effects of genotype and sex on the growth performance and carcass characteristics of broiler chickens. Tropical Animal Health and Production, 47: 12251231, 2015.

30.Siaga, R., Baloyi, J.J., Rambau, M.D., Benyi, K., Effects of stocking density and genotype on the growth performance of male and female broiler chickens. Asian Journal of Poultry Science, 11: 96-104, 2017. 